\title{
Classification and characterisation of smallholder farmers in South Africa: a brief review
}

Carelsen, C.P.R. ${ }^{1}$, Ncube, B. ${ }^{2}$, Fanadzo, M. ${ }^{3}$

Corresponding Author: B. Ncube. Email: NcubeB@cput.ac.za

\begin{abstract}
The South African agricultural sector has experienced various transformation processes over the past 25 years, from a predominantly white commercial sector to a black focused sector with an emphasis on smallholder farming. The government is committed to supporting the smallholder farming sector through interventions that include land reform and access to water, amongst others. Despite these efforts, smallholder farmers remain vulnerable, especially during drought periods. Smallholder farmers are not homogeneous; instead, they are diverse, and their farming needs also differ according to their livelihood needs. Due to the diversity of smallholder farmers, it is difficult for the government to effectively respond to their needs. The 2015-2018 drought is a case in point. This paper assesses the challenges of defining and classifying smallholder farmers in South Africa. The complex Western Cape classification system is presented as a case study. The study concludes that there is a need for a simpler method of grouping the smallholder farmers based on their livelihoods to develop relevant support systems.
\end{abstract}

Keywords: Farmer classification, support, livelihoods

\section{INTRODUCTION}

The South African agricultural sector has gone through various transformation phases since 1994, with a major focus on smallholder farming. The evolution of the agricultural sector as articulated by various academics and scholars indicates the change from a white commercial sector to a black focused smallholder sector (DAFF, 2011; Kirsten and van Zyl, 1998; Hendricks, 2014; Vink and Van Rooyen, 2009; Pienaar, 2013). With the new constitution in 1994 came the deregulation of core functions of the government, although some responsibilities still reside with the national government. Government portfolios were rearranged into either national or provincial skills, with agrarian capacities classed as common capabilities (Oettle et al. 1998; Van Niekerk, 2012). Currently, the Department of Agriculture, Forestry and Fisheries

\footnotetext{
${ }^{1}$ Extension officer, Western Cape Department of Agriculture, Private Bag X1 Elsenburg, 7607, South Africa. recardoc@elsenburg.com

${ }^{2}$ Lecturer, Centre for Water and Sanitation Research, Department of Civil Engineering and Surveying, Faculty of Engineering \& the Built Environment, Cape Peninsula University of Technology, Bellville 7535, Cape Town, South Africa. NcubeB@cput.ac.za

${ }^{3}$ Senior Lecturer, Department of Agriculture, Faculty of Applied Sciences, Cape Peninsula University of Technology, Private Bag X8, Wellington 7654, South Africa. Email: fanadzom@cput.ac.za. Orcid id: https://orcid.org/0000-0001-7777-7078
} 
is responsible for legislation and policy design while Provincial Departments of Agriculture implement the policies and legislation at the local level (Van Niekerk, 2012).

Tshuma (2014) demonstrated how the current national and provincial governments are committed to supporting the smallholder farming sector through various interventions that include food security and land reform programmes, amongst others. At the centre of the policies and development programmes is the inclusion of female and youth agriculturists (Hart and Aliber, 2012). Right from 1994, legislation focused on the empowerment of the most vulnerable women and youth (1995 White Paper on Agriculture, the 1998 Agricultural Policy in South Africa discussion document, the 2001 Strategic Plan for South African Agriculture and the 2004 Comprehensive Agricultural Support Programme). Government interventions aimed to rectify the injustices of the past and to foster the development of rural communities (Aliber and Cousins, 2013). Unfortunately, the remote location of many rural communities is limiting their access to formal markets and job opportunities; therefore, these communities rely on agricultural production for their livelihoods (Steward et al., 2015). The government and investors rely on smallholder farmers to produce food for their households and create jobs for rural communities (Steward et al., 2015).

The efforts of the government and related stakeholders to eradicate poverty and enhance rural economic development through agricultural development are under constant critique (Chikazunga and Paradza, 2013; Tshuma, 2014; Hart and Aliber, 2012). During the developmental initiatives, new challenges emerge. The challenges include the vulnerability of smallholder farmers to climate change, natural disasters, and social unrest, including land reform programmes that fail (Ubisi et al., 2017). The fact that policies are designed by the national government and the implementation of the policies is the responsibility of the provincial government render the response programs to disasters not effective, and the smallholder farmers are disadvantaged (Agri SA, 2016). The recent 2015-2018 drought in South Africa is a case in point. There is, therefore, a need to create a common understanding of the characteristics and challenges that are faced by smallholder farmers so that appropriate response programs can be developed for periods of disaster. This paper is a brief review of some of the challenges of classifying smallholder farmers in South Africa. The objectives of the study were to review the characteristics and critique the current classification systems of the smallholder farmers in South Africa and to show how they limit support to smallholder farmers. A case study of the Western Cape classification system is given to show the complexity of the current classification systems.

\section{THE SOUTH AFRICAN AGRICULTURAL SECTOR}

The agricultural sector in South Africa is well known for its duality with a strong commercial farming component on the one hand and the smallholder component on the other (Kirsten and Van Zyl, 1998; Mmbengwa et al. 2012; Pienaar, 2013; Thamaga-Chitja and Morojele, 2014; Hendriks, 2014). The commercial sector is dominated by white farmers who are also the drivers of the agricultural economy with export markets and sustainable investment arrangements; hence the commercial sector is perceived as the successful farming sector in South Africa 
(Tshuma, 2014; Mmbengwa, 2012; Hendriks, 2014). The success is attributed to support granted to the farmers from the South African Government for a long time (Tshuma, 2014).

The development of the rural agricultural sector has gained a lot of interest in the developmental arena since 1994 after the inception of the new government (Pienaar, 2013; Cousins, 2013; Thamaga-Chitja and Morojele, 2014). The South African Government focus is on capacity building of smallholder farmers as outlined in the National Development Plan (Pienaar, 2013). The Government intends to streamline support services towards the smallholder farmers to achieve the food security goals, including job creation and income generation for households. The National Development Plan states that the smallholder farming sector can build the rural economy through adequate extension and advisory services, increase in irrigated agriculture and cultivating of unproductive land in rural areas (DAFF, 2011; Cousins, 2013; Mvelase, 2016).

The private sector has also contributed to the development of smallholder farmers (Koch and Terblanchè, 2013). Different support services are provided to the farmers that vary from extension and support services, training, and mentoring and credit facilities where possible (Fanadzo and Ncube, 2018). However, the different stakeholders or partners in development find it difficult to streamline their support services to the desired target groups because there is no clear classification of smallholder farmers (Pienaar, 2013; Tshoni, 2015; Fanadzo and Dube, 2018). Cousins (2010) argues that literature fails to define smallholder farming because the different types of smallholder farmers are not considered. Van Averbeke et al. (2011) identified smallholder farmers as a group of households and individuals with several limiting factors that undermine their ability to embark on profitable interventions in the agricultural sector.

\section{DEFINING SMALLHOLDER FARMERS}

Various scholars and researchers attempt to define the smallholder farmers of South Africa (Cousins, 2013; Van Averbeke, 2011; Thamaga-Chitja and Morojele, 2014). Farmer typologies were previously used to categorise farmers into groups (Dunvernoy, 2000) and classify them. The diversity of different farmers was assessed using various variables to group farmers into different types (ibid). Farmer typologies have been mostly designed by academics, while the National Government also tries to categorise the smallholder farmers of the country. The South African Department of Agriculture (2015) defined smallholder farmers as those farmers who produce for household consumption and markets, subsequently earning ongoing revenue from their farming businesses, which form a source of income for the family. The farmers have the potential to expand their operations and to become commercial farmers but need access to comprehensive support (technical, financial, and managerial instruments).

Even though the government at large has promoted the continuous support of smallholder farmers for the past 25 years, information on these smallholders remains a scarce resource (Okunlola et al., 2016). The same authors also found critical contrasts amongst various groups of agriculturists who are frequently lumped together and identified shared traits that cut across 
their activities. Therefore, the term 'smallholder' or 'small-scale' is not helpful or enlightening, "and we need a more nuanced typology of black farming in South Africa" (ibid). Pienaar and Traub (2015) highlight the notion of referring to smallholder farmers by using different words that include small, small-scale, family, subsistence, emerging and smallholder. Smallholder farming households who rely on government grants as main sources of income are actively involved in agricultural production activities, mainly to supplement diets and reduce spending by buying less food from outlets (ibid). Smallholder farmers are not a homogeneous group of farmers who practice agriculture in the same fashion; instead, they are diverse, and their farming needs also differ according to their livelihood needs. This diversity amongst smallholder farmers makes it difficult to define the smallholder farmers (Pienaar, 2013; Tshoni, 2015; Fanadzo and Dube, 2018).

The Western Cape Department of Agriculture argued that the farming systems of the different producers are complex and their livelihoods strategies are diverse; therefore, support services targeted at these groups of farmers should be considered on farm level, taking into account the actual needs of the producers. The Western Cape Department of Agriculture continues to highlight that these producers should not be limited to government support but instead should be serviced by all the relevant actors in the sector on a comprehensive basis (WCDoA, 2017). Farmer typologies and definitions of smallholder farmers have been formulated to understand the smallholder farmers (Cousins, 2013; Greenburg, 2013), but the results do not create a clear understanding of these farmers. Perhaps using farmer livelihoods and resource endowment can provide a better understanding of the different types of smallholder farmers. However, little evidence has been found of studies examining the livelihoods strategies as a mechanism to characterise and classify the smallholder farmers.

\section{CLASSIFICATION OF SMALLHOLDER FARMERS IN SOUTH AFRICA}

Kirsten and Van Zyl (1998) discredited the attempt to classify smallholder farmers by using the size of the land as a variable because a high-value crop can deliver commercial outputs on a small piece of land such as one hectare, while five hundred hectares of low-quality land elsewhere might deliver low outputs. The authors suggested an interesting terminology for smallholder farmers: "A small farmer is one whose scale of operation is too small to attract the provision of the services he/she needs to be able to significantly increase his/her productivity." Kirsten (2011) suggested economic variables such as gross farm income, an amount of R500 000 and less farm income per year being suggested. However, this added to the complications that already existed. Greenburg (2013) identified two emerging issues. Firstly, using the economic variable to define smallholder farmers included subsistence producers or backyard farmers (farmers who maintained production only to supply food for their families). Secondly, all races were included; therefore it changed the landscape of the smallholder sector (Greenburg, 2013).

Smallholder farmers do not only produce food for the markets, but they also produce food for their own consumption (Van Averbeke and Khosa, 2007). The production of food by 
smallholder farmers in rural communities becomes very important because of its dual function (income generation and also the supply of food for the family), therefore contributing towards the rural economy (ibid). Greenburg (2013) put rural agricultural production development at the centre of the South African government. The contribution of smallholder farmers towards food security in the rural areas has resulted in the government and private sector acknowledging the smallholder sector as important in South Africa. However, two of the main characteristics of these farmers are their low education levels and the limited access to land, with some smallholder farmers having access to less than one hectare of land for agricultural production (Tshuma, 2014). These characteristics, with other challenges such as lack of finance, pose challenges for the farmers to continue to produce sustainably, especially during long periods of drought.

For the South African Government to successfully formulate support programmes and design policies to create a vibrant smallholder farming sector, it is important to clearly define the smallholder farmer (Fanadzo and Dube, 2018). The authors also propose the consideration of farm typologies or farming styles to give guidance and solutions upon establishing the smallholder farmers in South Africa. We argue that characterisation and classification based on livelihoods is a more accurate approach. Fanadzo et al. (2021) found that farmers who had access to livelihood capitals/assets tended to cope and adapt better to drought than those who did not in studies in the West Coast and Overberg Districts in the Western Cape. The literature clearly illustrates diversity amongst smallholder farmers and the complexities that arise in developing policies to support them. During natural disasters such as droughts, the South African government continues to use blanket approaches when supporting smallholder farmers. The latter may be due to the lack of a clear understanding of the smallholder farmers' needs. This gap demonstrates the need to develop a better understanding of smallholder farmers and their needs, especially during drought periods.

\section{CLASSIFICATION OF SMALLHOLDER FARMERS IN THE WESTERN CAPE}

The Western Cape Department of Agriculture has categorised the farmers of the province. Different descriptions of farmers coupled with support interventions are articulated. Table 1 shows the classification of farmers as stipulated by the Western Cape Department of Agriculture (WCDoA, 2018). Within subsistence and smallholder farmers, there are already four categories, and there is a group called small commercial farmers. 
S. Afr. J. Agric. Ext.

Vol. 49 No. 2, 2021: 97-106

http://dx.doi.org/10.17159/2413-3221/2021/v49n2a12821
Carelsen, Ncube \& Fanadzo

(License: CC BY 4.0)

TABLE 1: Classification of farmers stipulated by the Western Cape Department of Agriculture (Adapted from WCDoA, 2018)

\begin{tabular}{|c|c|c|c|c|c|c|c|c|}
\hline \multirow[t]{2}{*}{$\#$} & \multirow[b]{2}{*}{ Characteristics/Criteria } & \multicolumn{2}{|c|}{ Subsistence farmers } & \multicolumn{2}{|c|}{ Smallholder farmers } & \multicolumn{3}{|c|}{ Commercial farmers } \\
\hline & & $\begin{array}{c}\text { Urban/peri- } \\
\text { urban agriculture }\end{array}$ & Survival farmers & $\begin{array}{c}\text { Lifestyle } \\
\text { smallholder farmer }\end{array}$ & $\begin{array}{l}\text { Smallholder } \\
\text { farmers with } \\
\text { commercial } \\
\text { aspirations }\end{array}$ & $\begin{array}{l}\text { Small commercial } \\
\text { farmers }\end{array}$ & $\begin{array}{c}\text { Medium } \\
\text { commercial farmers }\end{array}$ & $\begin{array}{l}\text { Large commercial } \\
\text { farmers }\end{array}$ \\
\hline \multirow{3}{*}{1} & & \multicolumn{7}{|c|}{ Taxation } \\
\hline & VAT registration & No & No & No & No & $\begin{array}{l}\text { Some but voluntary } \\
\text { registration }\end{array}$ & $\begin{array}{l}\text { Yes, compulsory } \\
\text { VAT registration - } \\
\text { turnover is above } \\
\text { SARS specified } \\
\text { amount (R1m in } \\
2010)\end{array}$ & $\begin{array}{l}\text { Yes, compulsory } \\
\text { VAT registration - } \\
\text { turnover is above } \\
\text { SARS specified } \\
\text { amount (R1m in } \\
2010)\end{array}$ \\
\hline & $\begin{array}{l}\text { Qualify for income tax } \\
\text { deduction }\end{array}$ & No & No & No & No & Yes & Yes & Yes \\
\hline \multirow{5}{*}{2} & & \multicolumn{7}{|c|}{ Production intent } \\
\hline & $\begin{array}{l}\text { Production for } \\
\text { consumption or sale }\end{array}$ & $\begin{array}{l}\text { Predominantly } \\
\text { production for } \\
\text { consumption or sale }\end{array}$ & $\begin{array}{l}\text { Predominantly } \\
\text { production for } \\
\text { consumption or sale }\end{array}$ & $\begin{array}{l}\text { Predominantly } \\
\text { production for } \\
\text { consumption or sale }\end{array}$ & $\begin{array}{l}\text { Predominantly } \\
\text { production for } \\
\text { consumption or sale }\end{array}$ & $\begin{array}{l}\text { Predominantly } \\
\text { production for } \\
\text { consumption or sale }\end{array}$ & $\begin{array}{l}\text { Predominantly } \\
\text { production for } \\
\text { consumption or sale }\end{array}$ & $\begin{array}{l}\text { Predominantly } \\
\text { production for } \\
\text { consumption or sale }\end{array}$ \\
\hline & Intent to farm & Food security & Food security & Way of living & $\begin{array}{l}\text { Commercial } \\
\text { aspiration }\end{array}$ & Farm for profit & Farm for profit & Farm for profit \\
\hline & Market & Home & Home / informal & Formal & Formal & Commercial & Commercial & Commercial \\
\hline & Depend on Agric (cash) & $10 \%$ & $10 \%$ & $10-50 \%$ & $10-50 \%$ & Yes & Yes & Yes \\
\hline \multirow{3}{*}{3} & & \multicolumn{7}{|c|}{ Access to resources } \\
\hline & Access to land & No & Limited/Communal & Limited & Limited & Yes & Yes & Yes \\
\hline & Access to capital/credit & No & No & Yes & No & Yes & Yes & Yes \\
\hline \multirow{3}{*}{4} & & \multicolumn{7}{|c|}{ Other general characteristics } \\
\hline & Source of labour & Own/family & Own/family & Own/family/hired & Own/family/hired & Hired & Hired & Hired \\
\hline & Level of technology & Low & Low/indigenous & $\begin{array}{ll}\begin{array}{l}\text { Some } \\
\text { technology }\end{array} & \text { modern }\end{array}$ & $\begin{array}{ll}\text { Some } & \text { modern } \\
\text { technology }\end{array}$ & Modern technology & Modern technology & Modern technology \\
\hline
\end{tabular}


The definitions in Table 1 indicate that there is no all-encompassing classification of smallholder farmers even at the provincial level. The fact that it is difficult to define and classify the smallholder farmers makes it also difficult to respond to the needs of the farmers, especially during disaster events such as droughts. The current classification of farmers into different classes of farmers (subsistence, smallholder and commercial) is not helping much because the information needed to respond effectively to the needs of the different classes of farmers during disaster periods like droughts is lacking.

There is a need to consider other variables that exist amongst the farmers to characterise and classify them. The farmer characterisation and livelihoods approach is proposed as one such approach as already argued. However, little evidence has been found of smallholder farmer studies conducted in the Western Cape (Ncube, 2018; Ncube and Lagardien, 2015; Tshoni, 2015), especially towards examining the smallholder farmer characteristics. The Western Cape Province is also focused on fruit and wine exports. Furthermore, the Western Cape commercial farming sector is also known for its employment creation opportunities for people from various parts of South Africa, especially during fruit harvesting seasons (Nel, 2015). Therefore, there is a possibility of a mix of different individuals who may see themselves as smallholder farmers depending on the season. Fanadzo et al. (2021) recommend a need for in-depth livelihood studies that will consider wellbeing and try to understand the farmer's individual circumstances. The authors also recommended long-term socio-ecological studies to provide some of these answers.

\section{CONCLUSIONS}

The homogeneous concept employed by the government and extension service providers when developing support services for smallholder farmers is not helpful, especially during drought periods. There is a need for a more nuanced typology and classification of smallholder farmers to respond more effectively to natural disasters and climate hazards, using their livelihood needs. Characterising and classifying the smallholder farmers based on the livelihoods approach promises a more effective service delivery tool because it recognises theirentitlements, endowments, and capabilities. Furthermore, a long-term approach could provide the much-needed support to get smallholder farmers out of poverty.

\section{REFERENCES}

ALIBER, M. AND COUSINS, B., 2013. Livelihoods after land reform. Journal of Agrarian Change, 13(1):140-165.

COUSINS, B., 2010. What is a 'smallholder'?. PLAAS, University of the Western Cape, Working Paper, 16.

COUSINS, B., 2013. Supporting smallholders into commercial agriculture: A social dialogue and learning project. Proceedings of the First Innovation Lab. Cape Town. 19 September 2013. 
CHIKAZUNGA, D. AND PARADZA, G., 2013. Smallholder Farming: A Panacea for Employment Creation and Enterprise Development in South Africa? PLAAS Working Paper 27. Institute for Poverty, Land, and Agrarian Studies, September 2013

DEPARTMENT OF AGRICULTURE, FORESTRY AND FISHERIES (DAFF), 2011. National Framework for Extension Recovery Plan. Pretoria.

DEPARTMENT OF AGRICULTURE, FORESTRY AND FISHERIES (DAFF), 2014. Drought Management Plan: Department of Agriculture Land Reform and Rural Development: Northern Cape Province. Kimberley.

DUVERNOY, I., 2000. Use of a land cover model to identify farm types in the Misiones agrarian frontier (Argentina). Agricultural Systems, 64(3):137-149.

FANADZO, M. AND DUBE, E., 2018. Recognising the differences between farmers key to smallholder development. Water Wheel, 17(6):12 - 15.

FANADZO, M. AND NCUBE, B., 2018. Challenges and opportunities for revitalising smallholder irrigation schemes in South Africa. Water SA, 44(3) July 2018 ISSN 18167950 (Online) http://www.wrc.org.za

FANADZO, M., NCUBE, B., FRENCH, A. AND BELETE, A., 2021. Smallholder farmer coping and adaptation strategies during the 2015-18 drought in the Western Cape, South Africa. Physics and Chemistry of the Earth, Parts A/B/C, p.102986. https://doi.org/10.1016/j.pce.2021.102986

GREENBURG, S., 2013. 'The disjunctures of land and agricultural reform in South Africa: Implications for the agri-food system'. PLAAS Working Paper 26. Institute for Poverty, Land and Agrarian Studies, August 2013.

HART, T. AND ALIBER, M., 2012. Inequalities in agricultural support for women in South Africa. Human science research council: policy brief.

HENDRICKS, M., 2014. Connecting small-scale farmers in Grabouw, South Africa to formal markets: an assessment of the key constrains. Master Thesis, Wageningen University

KIRSTEN, J.F. AND VAN ZYL, J., 1998. Defining small-scale farmers in the South African context. Agrekon, 37(4):551-562.

KIRSTEN, J. F., 2011. "Most SA farmers are small-scale”, Farmers' Weekly, 23 September 2011, p. 38.

KOCH, A. AND TERBLANCHÈ, M., 2013. An overview of agricultural extension in South Africa. South African Journal of Agricultural Extension, 41(1):107 - 117.

KOECH, K.E., MUTAI, K.B., KIBET, K.L. AND KOSGEI, K.G., 2015. Determinants of market facilitators choice by smallholder farmers in Laikipia County Kenya. Journal of Agriculture and Veterinary Science 8(1):78 - 82.

LIEBENBERG, F., 2015. Agricultural advisory services in South Africa. Discussion Paper. University of Pretoria. 17 July 2015.

MMBENGWA, V., GROENEWALD, J., VAN SCHALKWYK, H.D. AND SEBOPETSA, M., 2012. An Evaluation of the Quality of Government Extension Services in West 
Coast District of Western Cape Province, RSA. OIDA International Journal of Sustainable Development, 4(12):113-126.

MVELASE, T. C., 2016. Developing practical solutions to problems and constraints faced by smallholder irrigation schemes in South Africa. Master Thesis, University of KwaZuluNatal.

NCUBE, B. AND LAGERDIEN, A., 2015. Insights into Indigenous Coping Strategies to Drought for Adaptation in Agriculture: A Karoo Scenario. Report to the Water Research Commission, WRC Report No 2084/1/15: ISBN 978-1-4312-0652-0, Bellville, South Africa.

NCUBE, B., 2018. Constraints to smallholder agricultural production in the Western Cape, South Africa. Physics and Chemistry of the Earth, Parts A/B/C, 106:89-96.

NEL, J.E., 2015. Successful integration of upcoming farmers in the commercial sector: A focus on the Western Cape. Master Thesis, Stellenbosch University.

NGAKA, M.J., 2012. Drought preparedness, impact and response: A case of the Eastern Cape and Free State provinces of South Africa. Jàmbá: Journal of Disaster Risk Studies, 4(1):1-10.

OETTLE, N., FAKIR, S., WENTZEL, W., GIDDINGS, S. AND WHITESIDE, M., 1998. Encouraging sustainable smallholder agriculture in South Africa. Environment and Development Consultancy Limited, Wales.

OKUNLOLA, A., NGUBANE, M., COUSINS, B. AND DU TOIT, A., 2016. Challenging the stereotypes: small-scale black farmers and private sector support programmes in South Africa. A national scan. PLAAS Research Report no. 53. Institute for Poverty, Land and Agrarian Studies, June 2016.

PIENAAR, L. AND TRAUB, L.N., 2015. Understanding the smallholder farmer in South Africa: Towards a sustainable livelihoods classification. International conference of agricultural economics. Agriculture in an interconnected world. 29 $9^{\text {th }}$ Milan Italy 2015. Universita Degli Studi Di Milano 8 - 14 August 2015.

PIENAAR, L., 2013. Typology of smallholder farming in South Africa's former homelands: Towards an appropriate classification system. Master Thesis, Stellenbosch University.

REPORT TO THE MULTI-STAKEHOLDER TASK TEAM ON DROUGHT., 2017. Agri SA's status report on the current drought crisis. February 2016.

THAMAGA-CHITJA, J.M. AND MOROJELE, P., 2014. The context of smallholder farming in South Africa: Towards a livelihood asset-building framework. Journal of Human Ecology, 45(2):147-155.

TERBLANCHÈ, S.E., 2013. Agricultural extension training needs of the non-government advising sector in South Africa. South African Journal for Agricultural extension 41:94 $-106$.

TSHUMA, M.C., 2014. Understanding the small-scale agricultural sector as a precondition for promoting rural development in South Africa. African Journal of Agricultural Research, 9(31):2409-2418. 
TSHONI, S., 2015. Analysis of smallholders' farm diversity and risk attitudes in the Stellenbosch Local Municipal area. Master Thesis, Stellenbosch.

UBISI, N.R., MAFONGOYA, P.L., KOLANISI, U. AND JIRI, O., 2017. Smallholder farmer's perceived effects of climate change on crop production and household livelihoods in rural Limpopo province, South Africa. Change and Adaptation in Socio-Ecological Systems, 3(1):27-38.

VAN AVERBEKE, W. AND KHOSA, T.B., 2007. The contribution of smallholder agriculture to the nutrition of rural households in a semi-arid environment in South Africa. Water SA, 33(3): 413 - 418.

VAN AVERBEKE, W., DENISON, J. AND MNKENI, P.N.S., 2011. Smallholder irrigation schemes in South Africa: A review of knowledge generated by the Water Research Commission. Water SA, 37:797-808.

VAN NIEKERK, J.A., 2012. Redefining the role of the extension agent in commercializing South African agriculture: An Eastern Cape case study. PhD Thesis, University of the Free State.

VINK, N. AND VAN ROOYEN, J., 2009. The economic performance of agriculture in South Africa since 1994: Implications for food security. Development Planning Division Working Paper Series No.17, Development Bank of South Africa: Midrand.

WESTERN CAPE DEPARTMENT OF AGRICULTURE (WCDoA), 2017. Recommendations report on appropriate commodity-specific thresholds and exit strategies. May 2017.

WESTERN CAPE DEPARTMENT OF AGRICULTURE (WCDoA), 2018. Lower Olifants River: Impact Assessment of the 2017/18 drought. August 2018. 